\title{
Determination of fermentation rates in maize land races used as forage in central Mexico*
}

\author{
J.G. Estrada ${ }^{1,3}$, O.A. Castelán ${ }^{1}$ and F.L. Mould ${ }^{2}$ \\ ${ }^{1}$ Centre for Research in Agriculture Sciences of the Autonomous University of the State Mexico \\ Literary Institute, No. 100 Colonia Centro, CP 50000, Toluca, México \\ ${ }^{2}$ Department of Agriculture, The University of Reading \\ Earley Gate, P.O. Box 237, Reading, RG6 6A, United Kingdom
}

\begin{abstract}
The maize plants are the main source of forage for dairy cattle in Central Mexico. The objective of this work was determinate fermentation rates in whole and plant structures by period, colour and zone. The experimental design used was a split plot. Significant differences $(\mathrm{P}<0.05)$ were observed in grain at 8 and $12 \mathrm{~h}$ by zone and colour. Leaves had significant differences $(\mathrm{P}<0.05)$ by period. Results suggest that the fermentation finish before of $40 \mathrm{~h}$ then it has no case to continue the fermentation until $120 \mathrm{~h}$.
\end{abstract}

KEY WORDS: maize, fermentation rate, gas production

\section{INTRODUCTION}

Smallholder maize livestock production systems, in which dairy cattle predominate, are the main form of agriculture in Central Mexico (Castelán et al., 2003). Cattle's feeding is based on maize crop residues. Maize is the main source of concentrates and forage during the whole year, but particularly during the dry season (November to May), and their use by farmers is an excellent example of efficient management of limited resources (Castelán et al., 2003). Highland maize cultivars developed by smallholder farmers through hundreds of years of careful selection (known as land races) have been collected over many years in order to develop new varieties suitable for highland areas of the world. Much of the

\footnotetext{
* Supported by the Universidad Autónoma del Estado de México and the ICAMEX-Government of the State of Mexico, Grants UAEM-1444/2000 and UAEM-1520/2001

${ }^{3}$ Corresponding autor: e-mail: julis@uaemex.mx
} 
selection has concentrated on grain production and little on forage production, however, for smallholder systems forages is as important as grain.

Despite the importance of maize land races in local systems, little is known about their nutritional characteristics particularly the fermentation rate in the different periods of utilization by farmers, knowledge of which would improve current feeding systems and make better use of available resources. The objective of this work was to determine the rumen fermentation rate characteristics of maize land races in the whole plant and plant structures in three maturity stages and three colours.

\section{MATERIAL AND METHODS}

\section{Plots selection}

Twenty four maize plots (individual farms) were selected in two contrasting zones in the central highlands of Mexico. Twelve were in Toluca Valley (Z1), $19^{\circ} 27^{\prime} \mathrm{N}$ and $99^{\circ} 38^{\prime} \mathrm{W}, 2650 \mathrm{~m}$ above sea level. The other 12 plots were from a mountain community (Z2) in the municipality of San Felipe del Progreso located in the north-western part of the state of Mexico, at $19^{\circ} 28^{\prime} \mathrm{N}$ and $99^{\circ} 52^{\prime} \mathrm{W}$ and $2800 \mathrm{~m}$ above sea level. In both areas maize land races are the most commonly grown crop. In both zones the main commercial maize colour is white which is sowing between 1 and 10 March, yellow and black maize are considered short cycle varieties (Vieyra-Odilon and Vibrans, 2001).

Three harvest periods $\mathrm{P} 1, \mathrm{P} 2$, and $\mathrm{P} 3$ were established in order to evaluate fermentation rate of maize at different development stages and to find the best harvest period to feed it to cattle. One week was allocated for sample collection in each period, namely the last week of August, October and November, 2001, respectively.

The chemical composition of analysed maize was, $\mathrm{g} / \mathrm{kg}$ DM: neutral detergent fibre 661 , acid detergent fibre 382, acid detergent lignin 50.8, crude protein 60.9, and soluble carbohydrates 196.3 .

\section{Determination of gas production (GP) and fermentation rates}

The gas production (GP) technique as described by Menke and Steingass (1988), modified by Nagadi et al. (2000a,b) was used. Rumen fluid was strained through double gauze and mixed with the buffer solution. Two hundred mg dried samples were incubated at $39^{\circ} \mathrm{C}$ with $30 \mathrm{ml}$ rumen liquor-buffer mixture in $100 \mathrm{ml}$ glass syringes, each sample was analysed by triplicate in the same day, and three syringes without substrate were used as blanks. Gas production measurements 
were taken at 1, 2, 3, 4, 5, 6, 7, 8, 12, 16, 20, 28, 36, 44, 52, 60, 72, 84, 96 and $120 \mathrm{~h}$ post incubation. Cumulative gas volumes for samples of leaves (L), stems $(\mathrm{S})$, husks $(\mathrm{H})$, rachis $(\mathrm{R})$, grain $(\mathrm{G})$ and whole plant $(\mathrm{WP})$ were corrected for blank gas production. After that, the fermentation rate was obtained getting the gas production in each measurement time and divided by the passing time (h) in each measurement.

\section{Statistical analysis}

The trial used a split-plot design with maize colour $(C)$ as the main plot with three levels: 1 = white maize, 2 =yellow maize and 3 =black maize. Growing periods (P) were split plots where 1, 2 and 3 represented the first, second and third periods, respectively, and the contrasting zones $\mathrm{Z1}=$ valley zone and $\mathrm{Z2}=$ mountain zone were used as blocking factors. Results were analysed according to the model:

$$
\mathrm{Yijk}=\mu+\mathrm{Zi}+\mathrm{Cj}+\delta \mathrm{ij}+\mathrm{Pk}+(\mathrm{C} \times \mathrm{P})+\mathrm{eijk}
$$

where: $\mu=$ overall mean, $\mathrm{Zi}=$ effect due to blocks $(\mathrm{i}=1,2), \mathrm{Cj}=$ effect due to colour $(\mathrm{j}=1,2,3), \delta \mathrm{ij}=$ residual error term for main plots, $\mathrm{P}=$ effect due to growing period $(\mathrm{k}=1,2,3), \mathrm{C} \times \mathrm{P}=$ interaction of period and colour and eijk=residual error term.

Results were analysed by analysis of variance and the difference between mean was calculated by Tukey test. The general linear model command of Minitab (2000) was used for the statistical analysis of plant structures and grain.

\section{RESULTS}

The results shown that the fermentation is presented in two sections, the first one represents the fermentation of soluble fraction which takes account generally in the first four to six h. The second one presents the fermentation of fraction insoluble but potentially fermentable, generally occurs after of $6 \mathrm{~h}$. The fermentation generally finishes at the $\mathrm{h} 36$.

The structure which presents the highest fermentation was the grain. Significant differences $(\mathrm{P}<0.05)$ were found by colour and zone. The lowest fermentation was observed in white grain maize (G-C1) and the highest in black maize (G-C3) (Figure 1). On the other hand, the grain fermentation was on the side $(\mathrm{P}<0.05)$ in the valley zone (Z1) because it has a fermentation of 5.78 (Figure 2).

In both cases the main differences $(\mathrm{P}<0.05)$ were observed at 8 and $12 \mathrm{~h}$ of fermentation. After $24 \mathrm{~h}$, the fermentation goes down and finished on $\mathrm{h} 40$. 


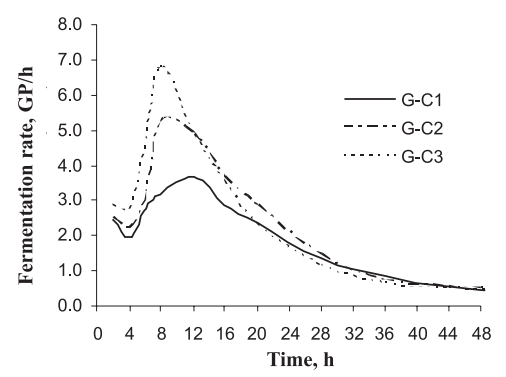

Figure 1. Fermentation rate in maize grain by colour

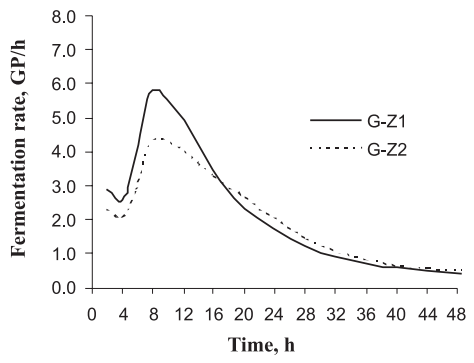

Figure 2. Fermentation rate in maize grain by zone

The leaves also presented significant differences $(\mathrm{P}<0.05)$ by period, especially at $12 \mathrm{~h}$. In this case the highest fermentation was observed in P1, P2 and P3 were similar $(\mathrm{P}<0.05)$. These results are presented in Figure 3 .

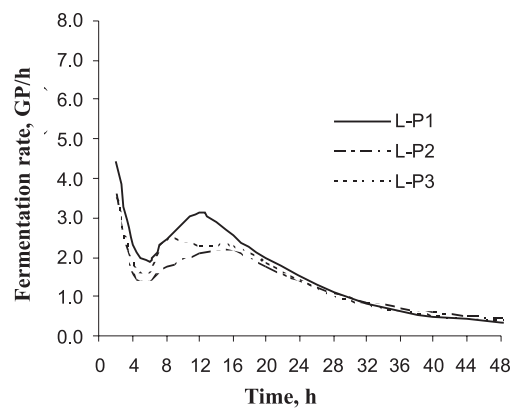

Figure 3. Fermentation rate in maize leaves by period

No differences $(\mathrm{P}>0.05)$ were observed in stem, husk, rachis and whole plant by period, colour and zone.

\section{DISCUSSION}

The fermentation before of $6 \mathrm{~h}$ presents the fermentation of soluble material, after this time the fermentation is represented by the fermentation of fraction insoluble but potentially fermentable also called the fermentation of neutral detergent fibre (NDF). This fermentation is according to Herrero and Jessop (1996) and Palmer et al. (2005) because their report that the fermentation of the soluble fraction (a) finish approximately after $4 \mathrm{~h}$. Then this fraction finishes it fermentation when the 
curve goes down $(6 \mathrm{~h})$ and the curve increase when the fermentation of the NDF started (as indicated in results). This phenomenon occurs in plants which contain an important component of fibre, in this case all the plant structures except the grain.

Although the grains diagram had similar structure fermentation in comparison with forage, their fermentation not corresponds to the same components. In this case the soluble fraction is the fermentation of pectins and the second fraction (after $6 \mathrm{~h}$ ) corresponds to the fermentation of starch.

The main effects were observed by period in which the fermentation decrease with the maturity of the plants as described by Tolera et al. (1998) and Tolera and Sundstøl (1999).

The method presented in this paper shown an option in which the gas production could be evaluated, not only adjust to an equation, in which a lot of information is lost.

\section{CONCLUSIONS}

The maize plant structure with the best fermentation was the grain followed by the husk. The plants maturity represents an adverse effect on fermentation. The results derived of this investigation suggest that the main effects were observed after 6 fermentation $\mathrm{h}$ and before of $24 \mathrm{~h}$. Basically, the fermentation finished at $40 \mathrm{~h}$ then it has no case to continue the fermentation until $120 \mathrm{~h}$.

\section{REFERENCES}

Castelán O.O., Fawcett R.H., Arriaga J.C., Herrero M., 2003. A decision support system for smallholder Campesino Maize-Cattle production systems of the Toluca Valley in Central Mexico. Part 1. Integrating biological and socio-economic models into a holistic system. Agr. Syst. 75, 1-21

Herrero M., Jessop N.S., 1996. Relationship between in vitro gas production and neutral detergent fibre disappearence in three tropical grasses. Anim. Sci. 62, 682 (Abstr.)

Menke K.H., Steingass H., 1988. Estimation of the energetic feed value obtained from chemical analyses and in vitro gas production using rumen fluid. Anim. Res. Develop. 28, 7-55

Minitab, 2000. User's Guide 2. Version 13. Data Analysis and Quality Tools. Minitab (USA)

Nagadi S., Herrero M., Jessop N.S., 2000a. The effect of fermentable nitrogen availability on in vitro gas production and degradability of NDF. Anim. Feed Sci. Tech. 87, 241-251

Nagadi S., Herrero M., Jessop N.S., 2000b. The influence of diet of the donor animal on the initial bacterial concentration of ruminal fluid and in vitro gas production degradability parameters. Anim. Feed Sci. Tech. 87, 231-239

Palmer M.J.A., Jessop N.S., Fawcett R., Illius A.W., 2005. Interference of indirect gas produced by grass silage fermentation acids in an in vitro gas production technique. Anim. Feed Sci. Tech. 123-124, Part 1, 185-196 
Tolera A., Sundstøl F., 1999. Morfological fractions of maize stover harvested at different stages of grain maturity and nutritive value of different fractions of the stover. Anim. Feed Sci. Tech. $81,1-16$

Tolera A., Sundstøl F., Said A.N., 1998. The effect of stage of maturity on yield and quality of maize grain and stover. Anim. Feed Sci. Tech. 75,157-168

Vieyra-Odilon L., Vibrans, H., 2001. Weeds as crops: The value of maize field weeds in the valley of Toluca, Mexico. Econ. Bot. 55, 426-443 